\title{
Women's Representation in the 2019 Legislative Election In Yogyakarta Special Region (DIY)
}

\author{
Dian Eka Rahmawati* \& Afiyatika Mufidati \\ Departement of Government Affairs and Administration, Universitas Muhammadiyah \\ Yogyakarta
}

Submited: 02 September 2020; Accepted: 15 December 2020; Published: 31 January 2021.

\begin{abstract}
Legislative elections are a democratic instrument for selecting candidates who are expected to be able to channel people's aspirations in policy making. The presence of female candidates is expected to be able to influence the policy-making process related to women's needs and interests. In the 2019 legislative elections in the Special Region of Yogyakarta (DIY) there was an increase in the number of women at the candidacy stage and the number of elected candidates compared to the 2014 legislative elections. This study aims to analyze the factors that influence the electability of female candidates in the 2019 legislative elections in DIY. The results of the study found that there were differences in motivation between elected and unelected candidates. Strong motivation provides encouragement for female candidates to try their best to campaign for themselves with various strategies. Motivation as the main factor is supported by factors of network breadth, social and political experience, support and family background, and popularity.
\end{abstract}

Keywords: women representation, legislative election, women electability

How to Cite: Rahmawati, D.E. \& Mufidati, A. (2021) Women's Representation in the 2019 Legislative Election In Yogyakarta Special Region (DIY). PERSPEKTIF, 10 (1): 180-186

*Corresponding author: ISSN 2085-0328 (Print)

E-mail: dianeka@gmail.com ISSN 2541-5913 (online) 


\section{INTRODUCTION}

Legislative elections are a democratic instrument to determine people's representatives in the policy-making process. It is hoped that the presence of women in the legislative body can inspire the needs and interests of women in government policies. The position of women is very important in the world of politics, women's representation in parliament certainly involves women in a strategic position in making decisions in favor of women (Priandi \& Roisah, 2019).

Currently affirmative policy in the form of quotas for women is considered an important first step to increase women's participation in politics. In Indonesia, this policy is expressly regulated in the regulations regarding elections. However, although normatively women's political rights are the same as men's, in reality many factors cause women's involvement and representation in politics is still low.

The 30\% quota policy for women in elections is still limited to the stage of candidacy as a condition for political parties to participate in elections. The seriousness of political parties in supporting women in parliament is still limited to meeting the $30 \%$ quota rule. As a result, women's access to strategic positions has not received the same equality. This can have an impact on public policies that have not adequately addressed women's issues and cause public excess that men feel is unfair and biased. (Izdiha, 2017; Partini, 2012; Ginting 2011). Therefore, the paradigm of women's participation in political parties must be changed (Maria et al., 2018; Sukma, 2018).

In another study, several factors support women's electability, such as economic capital, family, social skills, availability of campaign costs, and political party support. However, capital is often determined by the patriarchal political habitus which is generally dominated by men, which influences the mindset in various segments of the political life of society, at the individual, group, and political party organization levels. (Adeni \& Harahap, 2017; Ramadhany \& Rahmawati, 2020; Purwanti,
2015). On the other hand there are also inhibiting factors namely the crisis of women's trust from the community, low political education, minimal political costs (Realyta \& Rahmawati, 2020), and the urgency for women's representation in politics is hampered by negative stereotypes about women's abilities (Hardjaloka, 2012), In other terms, there is a political sexism. On the other hand, there is a perception of the responsibility of women in the domestic sector. Therefore, participating actively in politics can be a challenge for women (Kollo, 2017). Opportunities for women to occupy strategic positions are still limited. The view of women's roles and duties as housewives remains firmly rooted. Internal factors for women who still lack knowledge of organizational skills are also an obstacle to increasing women's representation (Fatmariza, n.d., 2015).

In the 2019 legislative elections in DIY, there was an increase in the number of female candidates, both in the candidacy and electability stages. In the 2014 legislative election, 8 female candidates were elected, while in the 2019 legislative elections, 9 female candidates were elected. Therefore, this study will focus on analyzing the factors that affect the electability of female candidates in the 2019 legislative elections in Yogyakarta.

\section{RESEARCH METHOD}

This research uses qualitative methods. Data collection was carried out by interview and documentation techniques. Interviews were conducted with representatives of women candidates who were elected and women candidates who were not elected in the 2019 legislature in DIY, as well as representatives of political party officials. Technique of collecting data through documentation is carried out from several sources such as books, articles, journals, and official websites from the KPU data relating to the representation of women and the factors limiting the representation of women.

\section{RESULT AND DISCUSSION}

Election regulations stipulate political parties to meet a minimum of $30 \%$ quota for women candidates as a condition for participating in elections. Based on data obtained from the KPU, in the 2019 legislative 
election in Yogyakarta, 15 political parties were participated with 316 male candidates and $258(55 \%)$ female candidates (45\%). In general, the quota of $30 \%$ of female candidates is fulfilled, even reaching almost 50\%. This condition has increased compared to the 2014 legislative elections in DIY, as can be seen in the diagram below:

Diagram 1.

Registered Candidate in 2014 and 2019 Legislative Election

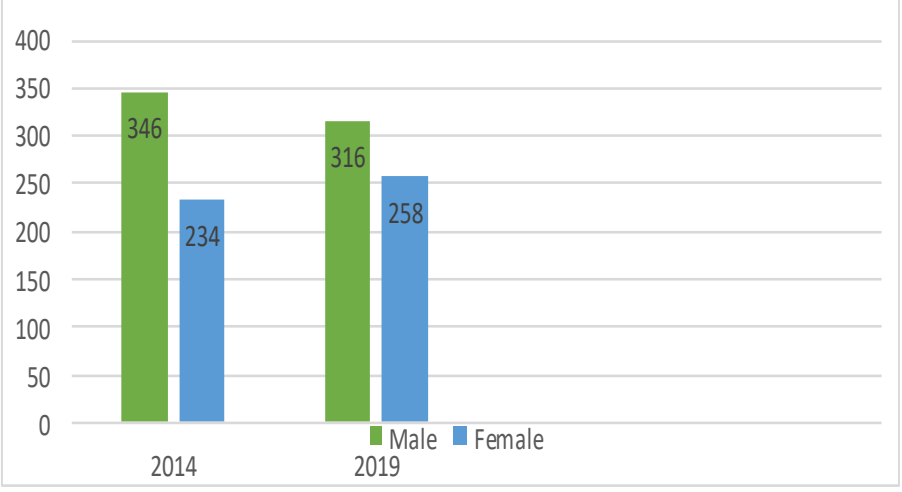

Source: www.kpu.go.id

The diagram above shows that the number of female candidates contesting the election increased by 24 and this increase helped increase the percentage of women participating in the election through a $30 \%$ quota. This growing number can be helped by the party, developing a strategy to exceed the $30 \%$ quota. Thus, until this stage of candidacy there were no problems with women's representation in quantity and each party has a strategy to meet the $30 \%$ quota of female candidates.

The National Mandate Party (Partai Amanat Nasional / PAN) and the National Awakening Party (Partai Kebangkitan Bangsa / PKB) are political parties that include the most female candidates. They have arguments and a commitment to include quite a number of female candidates in legislative elections. The following is the result of an interview with Mr. Bayu as the manager of PAN:

"Because the law has been agreed upon, so like it or not, we must obey. In fact, there is indeed an incentive for the government to encourage women's participation in the law on women's representation in various forms since 1999, so the law that makes it possible has existed since the law was enacted in the 1999 election. it is not new for PAN to be ready to represent it, and other laws have helped. Political party regulations, for example, also contain provisions on the management of women's representation."

One of the strategies carried out by PAN was to form a PAN branch group, especially for women and youth groups. PAN offers a platform for women to be actively involved in the organizations under PAN. The activities of the women's organization, which is under the auspices of PAN, are not only exploring political issues but also teaching exchange and social activities. In addition to women who are included in the branch of the organization under the auspices of PAN, PAN management also includes women in the management of their party by $30 \%$. Therefore, when viewed from human resources as women, for PAN it is not a big problem because this party has included and enabled women to play an active role in the management of the party or branch organization under the auspices of PAN.

But on the other hand, this strategy has not been fully successful in encouraging women to participate in elections. He said that not all women in the branch groups under PAN wanted to participate in the election, which was one of PAN's challenges. In other words, women's motivation to enter the political system by becoming members of parliament is still low. PAN's way of attracting women to participate in elections is by encouraging and supporting them, PAN can even provide funds for women who want to participate in elections to hold campaigns but do not have economic capacity.

"We will support and even provide funds, for example we have a one woman candidate, we know this woman does not have a strong economic capacity and we know that this woman may not qualify for the legislative seat. However, we still provide funds at least to make stickers or banners for the campaign. We do that to show our support as a supporting party". 
PKB has adopted a similar strategy. One of the strategies carried out by $\mathrm{PKB}$ is to encourage female candidates from PKB administrators and branch organizations, namely from the Women's Nation and Gemasaba organizations, as well as from administrators who have reached $30 \%$ so that in terms of resources to meet the $30 \%$ quota. not a big deal. In addition, PKB also provides appreciation or rewards for female candidates who get votes.

The problem that then arises is that the electability of women in legislative elections is not linear with representation in the candidacy stage. This data can be seen in the diagram below:

Diagram 2.

Comparison of Registered Candidates and Elected Candidates

In the 2019 Legislatif Election in DIY

Registered Candidates

Elected Candidates

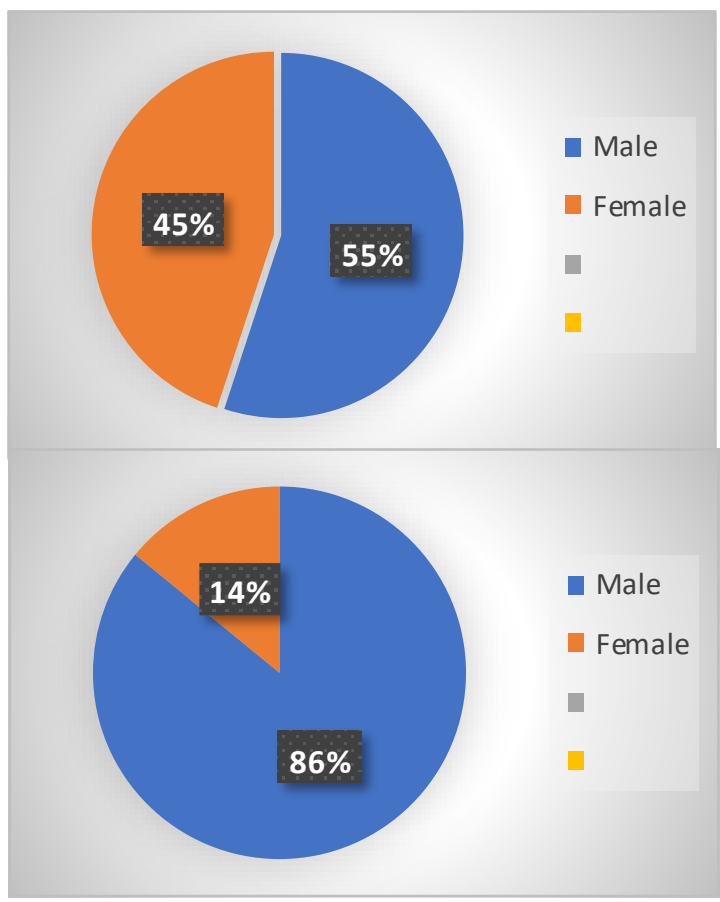

The diagram above shows that there is a fairly high gap between female candidates and elected female candidates. If during the candidacy stage, women's representation reached $45 \%$, but only $14 \%$ of female candidates were elected. Based on data obtained from the KPU, in the 2019 legislative elections in DIY, there were 55 male and female candidates elected, but of these only 9 female candidates were elected. Although, in the 2019 legislative election there was an increase in the number of elected female candidates compared to the 2014 legislative election, which only had 8 female candidates elected.

This was also emphasized by Mrs. Siti Nurjannah, one of the elected candidates who is now a legislator in the DIY DPRD:

"The number of female representatives who passed this election is still very small. Although the party has tried to meet the $30 \%$ quota for women in registration. However, they still do not succeed in achieving the 30\% quota for women, even still far from the target".

By setting a quota of $30 \%$ women's representation, it should provide a more significant opportunity to place women in legislative positions proportionally. The existence of a $30 \%$ quota also encourages political parties to attract the masses of women to participate in the candidacy in order to meet election requirements that require representation of $30 \%$ women. The representation of women is expected to be able to provide a balance when making regulations or in making decisions. In addition, with the presence of women, the problems of women and children can be touched because of the representation of groups at the legislative level. However, the position of women in their candidacy is not easy. The seriousness of political parties in supporting women in parliament is still limited to meeting the rules regarding the $30 \%$ quota. Therefore, women's access to strategic positions has not received the same equality. This can have an impact on public policies that do not adequately address women's issues and cause public excess that men feel is unfair and biased.

Political parties have not played an optimal role in preparing women candidates to compete in legislative elections. Even though some parties provide some financial subsidies for campaigns, this has not yet touched on the substance of empowering women candidates. Actually, political parties can carry out political capacity building for female cadres, so that 
they have the knowledge, skills, motivation, and confidence to compete in legislative election contestation. In addition, fair and clear rules of the game are needed in determining serial numbers and electoral districts. However, in practice, party oligarchy with patrairki nuances still dominates.

The issue of women's motivation to be involved in practical politics as members of parliament is one of the determining factors. Apart from the results of interviews conducted with political party officials, similar statements were also obtained from several female candidates. One female candidate who was not elected from PKB said that during the campaign period they had no ambition to win. They are willing to be nominated to help political parties meet the minimum quota of $30 \%$ women and to give the party the number of votes.

The issue of motivation was also expressed by one of the women candidates who were elected from PAN, that she decided to become a candidate for the legislative elections because she had strong motivation and motivation to be able to contribute more to society. By advancing to become legislative candidates, informants believed that they could have more open access to provide benefits to society.

Another elected female candidate from PAN, Hanum Salsabiela Rais, who is the daughter of a national political figure, Amien Rais. He decided to run as a candidate because he had strong motivations to influence prosociety policy making. Furthermore, from the interviews quoted from Tagar.id, the informant explained that what motivated him was the desire to contribute to the wider community through political channels. From this, it can be seen that there are differences in motivation that can affect the success rate of female candidates to pass the election.

In the classification of women's representation, according to (Mukarom, 2008) there are 3 groups of women in the representative classification as follows. The first group. Women get political positions in this group, because they have relationships with people who have political power or authority. Her father, for example, was a representative of her local government, so her daughter would directly influence her father to get involved in political affairs and earn her father's reputation. Second group. Women have no domestic responsibilities, which means they don't have to look after their children. So, they can focus on their political career. The third group. Usually this group is dominated by middle-aged women who have worked in politics and in previous organizations.

Beside on the data on the field, candidate who passed namely Hanum Salsabiela Rais if analyzed using the Mukarom theory, she can be classified in the First Group because she has relationships with people who have political influence or authority. By this, she can be influenced by her father that involved in political matters and get a reputation from the reputation of her father. Meanwhile candidate who qualify namely Siti Nurjannah can be classified in the Third Group because she is a middle-aged woman who already have a carrier in political things and act in an organization before. This is supported by the results of interviews with informant who said that previously informant was active in organizational activities.

From the results of interviews with several selected female candidates, it was stated that the factor of high level of education did not guarantee electability. The factors of organizational experience, ability to build networks, support and family background, as well as the candidate's popularity among the community determine their electability.

"I have a strategic position in PKB. My family understands and supports my political career, because I was already organized since I was little. As for politics, for now I'm happy to participate. Prior to joining politics, I had long been active in social and religious activities. "

The worry that arose from one of the elected candidates was when female candidates competed against female candidates in the same electoral district, as said by Ms. Siti Nurjannah as the selected candidate said that: "The obstacles are mainly due to a big number of candidates. The number of candidates can all sometimes be in one location or area, so we take care of each other too". This explains that the informant encountered an obstacle in the form of many candidates coming forward this year so that the informant had a concern not being 
accepted because of other candidates in one same location.

Thus, this research finds several important things in the electability of women in the 2019 legislative elections in DIY. First, the number of female candidates during the candidacy stage and the increase in the number of female candidates elected in the 2019 legislative elections have increased. However, there is still a sharp gap between female candidates participating in the election and the elected female candidates. This strengthens the results of previous research that women in legislative election contestation are still only a complement to fulfilling the $30 \%$ quota requirement by political parties.

Second, there are several factors that affect the electability of women in the legislative elections in this case, namely motivation, organizational experience, the ability to build networks, support and family background, and the popularity of candidates in the community. Motivation is a fairly dominant factor that differentiates between elected and unelected candidates. The elected candidate, in this case, had the motivation from the start to enter the political system by becoming a legislator. Motivation becomes energy to contest in legislative elections and manage the modalities they have. Not many women have this motivation. This study also still finds that many female candidates are simply oriented towards helping parties meet quotas and contribute votes to parties. On the one hand, this makes political parties lack capable female cadres who seriously want to enter the political system as legislators. This condition is related to the first finding that political parties have not played a maximum role in preparing women candidates, starting from the cadre stage to building the capacity of female cadres to compete in legislative elections.

\section{CONCLUSION}

Based on the results of research and data analysis, it can be concluded that: first, this study strengthens several previous studies that women's representation in legislative elections and in parliament is still limited to fulfilling the $30 \%$ quota during the candidacy stage. Second, this study found that there were differences in motivation between elected and unelected candidates. Strong motivation provides encouragement for female candidates to try their best to campaign themselves with various strategies. Motivation becomes energy for women to contest in legislative elections. Other supporting factors for the electability of female candidates are the ability to build networks, organizational experience, support and family background, as well as the candidate's popularity in society.

\section{REFERENCE}

Adeni, S., \& Harahap, M. A. (2017). Komunikasi Politik Dan Keterwakilan Perempuan Dalam Arena Politik. Jurnal PERSPEKTIF Komunikasi, Program Studi Ilmu Komunikasi Dan Magister Ilmu Komunikasi Fisip Universitas Muhammadiyah Jakarta, 1(2), 7.

Artina, D. (2016). Keterwakilan Politik Perempuan dalam Pemilu Legislatif Provinsi Riau Periode 2014-2019. Jurnal Hukum IUS QUIA IUSTUM, 23(1), 123-141. https://doi.org/10.20885/iustum.vol23.iss1. art7

Fatmariza. (2015). Representasi Perempuan dalam Lembaga Legislatif di Sumatra Barat Pasca Quota 30\% (n.d.). 49-61.

Ginting, E. N. (2011). Representasi Perempuan di Parlemen Indonesia. Politeia, 3(2), 113-122.

Hardjaloka, L. (2012). Potret Keterwakilan Perempuan dalam Wajah Politik Indonesia Perspektif. Jurnal Konstitusi, 9(15), 28.

Izdiha, A. (2017). Wajah Politik Perempuan: Studi Etnografi Representasi Suara Perempuan dalam Pemilu Legislatif 2014 di Propinsi Daerah Istimewa Yogyakarta (DIY). Jurnal Pemikiran Sosiologi, 4(2), 36. https://doi.org/10.22146/jps.v4i2.28579

Kollo, F. L. (2017). Budaya Patriarki dan Partisipasi Perempuan dalam Bidang Politik Budaya Patraiki. (November), 321-322

Maria, A., Quintarti, L., \& Djou, G. (2018). Partisipasi Perempuan dalam Partai Politik dan Pemilu Serempak. Seminar Nasional Hukum Universitas Negeri Semarang, 4(3), 601-610.

Mukarom, Z. (2008). Perempuan dan Politik : Studi Komunikasi Politik tentang Keterwakilan Perempuan di Legislatif. MediaTor: Jurnal Komunikasi, $\quad 9(2), \quad 257-270$. https://doi.org/10.1016/j.patrec.2006.10.01 2

Priandi, R., \& Roisah, K. (2019). Upaya Meningkatkan Partisipasi Politik Perempuan Dalam Pemilihan Umum Di Indonesia. Jurnal Pembangunan Hukum Indonesia, 1(1), 106. https://doi.org/10.14710/jphi.v1i1.106-116

Rahmawati, D. E., \& Muslikhati, S. (2005). Partai politik Islam dan Pemberdayaan Politik Perempuan: Studi Deskriptif tentang Strategi 
Dian Eka Rahmawati \& Afiyatika Mufidati, Women's Representation in the 2019 Legislative Election In

Pemberdayaan Politik Perempuan oleh DWP PPP, DPW PKS, dan DPW PBB Propinsi Daerah Istimewa Yogyakarta pada Pemilu 2004: laporan penelitian. Fakultas Ilmu Sosial dan Ilmu Politik, Universitas Muhammadiyah Yogyakarta.

Ramadhany, D., \& Rahmawati, D. E. (2020). Modal Caleg Perempuan dan Politik Patriarkhi dalam Pemilihan Umum di Indonesia:
Keterwakilan Perempuan pada Pemilu 2019 di Kabupaten Sleman. JISPO Jurnal Ilmu Sosial Dan Ilmu Politik, 10(1), 39-62. https://doi.org/10.15575/jispo.v10i1.7237

Realyta, E. B., Rahmawati, D. E., \& Yogyakarta, U. M. (2020). Representation of Women In The 2019 Election In Gunungkidul District. 20(1), 30-43. 